Western University Scholarship@Western

Centre for the Economic Analysis of Property Centre for the Economic Analysis of Property

Rights. Economics and Law Workshop Papers

Rights

1984

\title{
Diffusion of Knowledge-Based Products: Applications to Developing Economies
}

M. L. Burstein

Follow this and additional works at: https://ir.lib.uwo.ca/economicsceapr_el_wp

Part of the Economics Commons

Citation of this paper:

Burstein, M. L.. "Diffusion of Knowledge-Based Products: Applications to Developing Economies." Centre for the Economic Analysis of Property Rights. Economics and Law Workshop Papers, 84-05. London, ON: Department of Economics, University of Western Ontario (1984). 


\section{ECONOMICS AND LAW WORKSHOP}

$$
\text { 84-05 }
$$

DIFFUSION OF KNOWLEDGE-BASED PRODUCTS :

Applications to Developing

Economies

M. L. Burstein

Feb. 9, $1984 \quad 4107$ sSC 4:00 p.m.

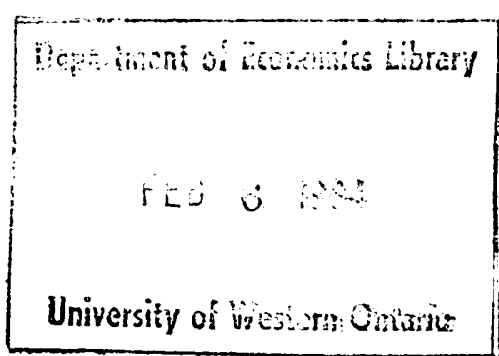

Major funding for the Centre for Economic Arialysis of Property Rights has been provided by the Academic Development Fund, The University of Western Ontario. Additional support has come from The Bureau of Policy Coordination, Consumer and Corporate Affairs. The views expressed by individuals associated with the Centre do not reflect official views of the Centre, The Bureau of Policy Coordination, or The University of Western Ontario.

Subscriptions to the Workshop papers and the Working Paper Series are $\$ 40$ per year for institutions and $\$ 25$ per year for individuals. Individual copies, if available, may be purchased for $\$ 3$ each. Address all correspondence to John Palmer, Centre for Economic Analysis of Property Rights, The University of Western Ontario, London, Ontario, CANADA N6A 5C2. 


\section{DIFFUSION OF KNOWLEDGE-BASED PRODUCTS:}

Applications to Developing Economies

M. L. Burstein

Professor of Economics,

York University

\section{INTRODUCTION: KNOWLEDGE AND DEVELOPMENT}

Typically, a developing country's potential benefit from a new idea is based on its learning how to apply the knowledge imbedded in the idea and controlling the products and processes flowing from it. Indeed praxis entails a corollary body of knowledge. Then new things can be accomplished in new ways.

Markets for products and processes based on new ideas usually. must be created. And this is especially true in developing economies: there economically-effective knowledge is apt to be especially scarce. Effective use of knowledge-based products typically depends on diffusion of other knowledge, including, of course, knowledge needed to utilize the core product. One has to be taught to use the software, generally speaking, that makes the hardware effective. Indeed the hardware/software image is important for the paper.

Markets for knowledge-based products often can be developed only through the intellectual and financial resources of innovating companies. There thus emerges another key concept: bundling of "hardware" and "software", especially in early stages of product-diffusion. Bundling in turn nests within another central concept, that of complementarity of products. Software is complementary with hardware.

\section{Successful-}

knowledge-based product . of operating the product. Then vertical integration becomes a characteristic mode of operation, especially in less-developed economies. Innovating companies often are uniquely well placed to explain what to do with their ideas. 
Another central concept concerns free riding. Knowledge-based products typically cannot adequately be diffused, if indeed they can be created at a11, except by expenditure of what may be vast sums. And the diffusion process typically is strongly inertial: propagation of knowledgebased products, together with their modes of employment, may require innovators to incur huge. losses "up front". Nor can these losses be redeemed if innovators are denied property rights in their products and associated hardware. Patents and copyrights are, of course, prominent among such property rights. Only recently has it become understood that - - sets of actions intended to promote private profit are extremely sensitive to the installed régime of property rights. Once this point is taken, it becomes obvious that law and economics are intimately linked: private profit cannot be harnessed to public interest if the régime of property rights is not optimal. It becomes obvious that this paper is. more concerned with marketing than with initial invention. A study of diffusion needs must be so. Furthermore, less-developed economies naturally are more concerned with utilization of knowledge developed in advanced economies than with incremental contributions to root knowledge they may make now. For these reasons, the root concepts of the paper are those controliing the outcome of fundamental new knowledge rather than the creation of such knowledge. **

A peculiar dimension of our analysis concerns the way in which decay, in a certain sense, complements diffusion. The proportion of social benefit appropriable by the innovator (often denoted the Company)may be small even under the most favorable (to the Company) circumstances. Thus consider the thermodynamical concept of available heat energy. When heat-fall is harnessed in the most perfect manner conceivable, only a.fraction of the falling heat-energy can be transformed into work. 
It becomes natural to ask the following question:

Is there a tendency towards increasing resistance to the ability of an innovator to appropriate returns from development of a knowledge-based product? Does the ability to appropriate such returns decay with time?

Yes! Indeed the decay factor can make it necessary for host economies to pay that much more in advance, or expand fields of protection, if it is to induce entry of products requiring substantial market-development expenditure, $\underline{i}$. $\underline{\text { front }}$ loading. Pakes $q$ Schankerman(1978) have made our point in an especially-interesting way:

"The rate of decay in the revenues accruing to the producer of an innovation derives not from any decay in the productivity of knowledge but rather from two related points regarding its market valuation, namely that it is difficult to maintain the ability to appropriate the benefits from knowledge... Indeed, the very use of the new knowledge in any productive way will tend to spread and reveal it to other economic agents, as will the mobility of scientific personnel. (Emphasis supplied.) One might expect then that the rate of decay of appropriable revenues would be quite high, and certainly greater than the rate of deterioration in the physical productivity of traditional capital."

$$
\text { op. cit. . p. } 3 .
$$

"Decay" poses obstacles to "hosts" as well as to innovators. The decay-quandry might abort diffusion-effort. And straightforward patent-protection might be an insufficient antidote. More-complex product/marketing combinations might have to be put into play. The upshot leads to applications and.extensions of work done by Burstein(1960a, 1960b) and Telser $(1960,1979)$ in the fields of tied sales, full-line forcing, resale price maintenance and monopolies of complements. Resulting analysis, necessarily dense, must be worked through step by step; capsulatization cannot be efficient. (Cf infra.) But the flavor of the outcome is suggested by the following colloquy.

Q. To the extent that host economies are asked by innovating companies to grant patent protection to groups of products, groups including products not very interesting to hosts(and which may be available at lower prices from "pirates"), are they not being asked to grant extensions of monopoly from Product $A$ to Products $B, C, . ., Z$ ? Where $A$ is the key product, are not patentees than "piggybacking" $B, C, ., \ldots$ on $A$ ? 
A. Nol It may be impossible for an innovating company to recover what may be massive overheads (including those pertaining to product-introduction and user-education), let alone profits mandated by the cost of capital, unless a large-enough product-line can be established and protected--especially if property-rights in spin-off from primary products are not created in favor of innovating companies. The field over which an innovating firm finally exercises control may have to encompass quite-broadly-defined productgroups.

Furthermore, a marketer may not find it worthwhile to offer rich packages of complementary services unless he freely can form groups (bundles) of complements geared to different sorts of users.

In theory one easily identifies the lead product among a group of products. In Life, it may be impossible to determine ex ante which of products $A, B,$. . . is the lead one. Such uncertainty is endemic in "new knowledge" situations. It cannot be clear ab initio what are the full implications of new discoveries. However, when patents are respected au général, the self interest of innovating companies can assure that products with high benefit-potentials are intensively enough marketed. The analysis illustrates the way in which economic efficiency is affected by the régime of property rights.

Pursuing discussion of "property rights and optimality, ideally, if information is complete and the forces at work are certain, innovating = companies would be rewarded by lump-sum bounties. In the real world, reward-mechanisms must be devised that are feasible under prevailing political conditions; and the mechanisms must take account of the costs of engaging in real-world transactions and operating mechanisms under uncertainty. The optimal feasible solution will be second-best, or $n$-th best

the economic-development context

Admittedly, my analysis is not particular to a less-developed

economy. Indeed one of the characteristics of advanced economies concerns the frequency of invention and the rapidity of diffusion of perhaps radically new idead. But the analysis is important, perhaps crucially so, for developing, or simply less-developed, economies: the modern theory of development . A stresses the rôle of knowledge and its diffusion.

Economic development commonly has been perceived to be an extensive process: It has been hoped that, as more and more capital, usually measured by constant-dollar expenditure on physical durables by producers, is accumulated per worker, output per head, net of capital cost, will increase. Such hopes 
commonly have been disappointed. Indeed, massive investment programs often have led to, or not prevented, lower per capita incomes in less-developed economies: steel mills and chemical plants, let alone state-owned air-lines, have sucked in more valuable resources than they have yielded. Extensive perceptions of economic development insufficiently consider, when they do not ignore, knowledge and investment in human agents.

In modern theory, economic development significantly is perceived to be an intensive process. Development is seen as a process in which people learn to do different things in different ways, attracting profit-seeking capital as they go along.

Reflecting further on. intensively-perceived development-sequences, resources of the host country are attracted to a nucleus based on imported knowledge. Then newly-trained human capital may push outside the boundaries of the originally-innovating companies, often becoming licensed to supply software, to distribute hardware, etc. Still later, the skills and experience accumulated in this way may lead new middle classes to import additional technology on their own. They may perceive possibilities that cannot be obvious to World Headquarters: so to speak, maps at Worl ${ }^{\mathrm{d}} \mathrm{HQ}$ are on too large a scale. Host-country "second round" innovators thus may be able to tap local savings and evoke. fresh savings, attracted to newly-created opportunities--keeping in mind that, in simpler financial nexi, savings are a function of investment opportunity. Derived development of this sort may lead to derived demand for the technology of highly-developed economies through a feedback channel.

2. PRELIMINARY GLIMPSE OF THE MODERN THEORY OF THE DEVELOPMENT OF MARKETS FOR KNOWLEDGE-BASED PRODUCTS

"ogives"

Griliches(195-), in his landmark study of the diffusion of the hybridcorn idea, implanted into economics the ogive concept, long known in biometrics. (An ogive is the distribution curve of an accumulative frequency distribution. 
The process exhibits accelerated growth over a crucial segment.) Ogive-based processes are strongly inertial..$^{2}$ Once a certain critical mass is attained, a marketing breakout becomes possible. Often, if not usually, inertia can be overcome only by massive expenditures by the innovating company--initially at least the custodian of knowledge of what can be done with the product--in the early stages of product-development in a new market, a market that typically must be created. Resulting, heavily-front-loaded, plans may be financially justifiable only if innovating companies can foresee virtual protection over a long horizon.

bundling, resale price maintenance(IPM), etc.

Deep-lying analogies for the problem at hand can be drawn from modern ecomic theory, specifically from the theories of "blndling" and RPM; at least that part of the theory of RPM that is concerned with assurance of substantial mark-ups for downstream promoters and distributors.

In modern economics, products are perceived as bundles of properties. Especially stressed are information and knowledge. Economists now study the costs of acquiring and diffusing knowledge in the same way they long have studied the cost of extracting and distributing coal. ${ }^{2}$

If a layman bought a personal computer, the hardware would be but a toy for him until he learned how to use the machine. Programs would have to be selected, or devised, for him. He would have to be taught how to manipulate the materials. His progress would have to be monitored and his experience studied so that knowledge generated in this way could lead to improved programs,

\footnotetext{
${ }^{2}$ See M. Trajtenberg (1982), "The Effects of Regulation on the Diffusion of.CT Scanners" (Cambridge Mass: National Bureau of Economic Research; Oct.). Also see M. Trajtenberg \& S. Yitzhaki(1982), "The Diffusion of Innovations: A Methodological. Reappraisal" (Unpublished). Trajtenberg(1982) writes that: "there is no unique way to characterize diffusion processes;...the choice of parameters...alw:!s retains an element of arbitrariness.", op. cit., p. 3.

${ }^{2}$ This, and the following four paragraphs, are based on Burstein (1982).
} 
etc.

Contrast the last example with one based on the computer operations of a huge, technologically sophisticated, company operating complex computerguided processes. Such a company is likely to have vast sotware capability. It is likely to buy unbundled computer products. It will buy hardware, which it may help design; it will not pay computer companies for instructional materisls.

The insurance industry supplies another example of the logic of "bundling". When an insurance product is new, commissions-on-sales dominate agent-compensation, encouraging agents to introduce and promote the product. As the market matures, and if Regulation permits, agent-compensation will become disassociated from what had been a new product. The process will become unbundled. Conventional, annualized salaries will be paid for agent-services increasingly concerning ordinary maintenance of the existing stock of policies. One asks, as did Telser(1960), "why should manufacturers want fair trade?". In early stages of development of markets for knowledge-based products, it often is important that distributors explain them to consumers. Such explanations may be time-consuming and expensive. Distributors will be prepared to do this work only if offered high mark-ups. So, in the early days of stereos, advanced cameras and like products, manufacturers do tend to want fair trade (RPM) .

If a knowledge-based product is very complex--computers, together with associated software and operational techniques, are an excellent example; others are found in drugs and agricultural chemicals--the most-effective marketing (diffusion)mode may be vertically integrated. The innovating manufacturer's unique command of the theory and praxis of the "product atom", comprised of a hardware nucleus orbited by software(praxis)electrons may make vertical integra:ion inevitable. Indeed, only recently, even in highly-developed economies, have software industries truly broken free from the powerful pull of the field set w by the knowledgability of original-equipment manufacturers(OEM) - Originators $\mathbb{E}=:$ 
have to shepherd the diffusion of complex products if these are to be useful. Resulting diffusion processes may require huge expense "up front". Large sums may have to be spent on new colleges before teaching can begin; students may have to be trained for years before they can deal effectively with difficult problems.

property rights

Continuing our tour of the component-parts of the modern theory of the diffusion of knowledge-based products, we somewhat elaborate on the propertyrights idea. Prompt intersection with two other basa ${ }^{1}$ concepts--free riding and multi-product production and distribution--is inevitable.

Efficiency of economic performance can significantly depend on how property rights are assigned. This is especially true for innovation and trading in the fruits of innovation.

The assignment of rights to land along railroad rights of way to railis an road comapnies in the 19th century in North America comprisesin sinpid example of the sort of policy problem we are studying. The bothoniclspin-off from railway-development was immense. Whole regions became agriculturally viable for example. But it was not so clear that potential profit from hauling produce and people was great enough to provoke entrepreneurs to make the huge, risky investments that were required. Assignment to the Companies of rights to 1and, land whose value was enhanced by railway-building, allowed the Companies to claw back substantial spin-off from their activity (and more according to Ida Tarbell et al).

Property-right assignment may be important for more-or-less defensive reasons as well as for capture of spin-off. During earlier, loss-making phases of diffusion, the Company is likely to have no rivals in the field. Potential rivals then are glad to take a free ride. And the same factors that finally overcome inertia and make the market potentially profitable are likely to 
make it impossible for the Company to dominate the market once it has ripened. Indeed successful diffusion may accelerate decay of the Company's appropriability coefficient: the same diffusion process that ripened the market is likely to have greatly enhanced Understanding by the Company's potential rivals. Unless the Company can obtain sufficient property rights over affected products and processes for sufficiently-long intervals, it may decide against introduction of innovative products. And it is certain that incomplete property-right investiture will lead to socially suboptimal diffusion. ${ }^{3}$

It will prove critical that the property-rights analysis cover $\underline{\mathbf{n}}$ products at all times. It suffices now to point out that usually it is infeasible to market even "breakthrough" products except en échelon with what might be a large number of other products, most of which may be solid but unexceptional.

transactions costs

Transactions costs are one of the heavyweight concepts of modern economics. We treat the frictions of much political-economic dealing as transactions costs, reflecting the difference between the friction-free world of traditional pure theory, together with traditional assumptions of perfect information and costless search, and the real world. Thus it may prove infeasijle for an innovator to capture much of the spin-off(called external economies) from

\footnotetext{
${ }^{3}$ The following set of papers is concerned with precisely the problem of greates: interest to us, $i$. e. optimal diffusion. Granted, the depletion analogy is not ideal for the study of diffusion of knowledge; knowledge is inexhaustible.

The papers include: Yoram Barzel (1968); Edmund Kitch(1977, 1980); Douglas A. Smith \& Donald G. McFetridge (1980; and an unpublished paper by S. N. S. CherEg.

Kitch(1977) reports that his ideas "crystallized in response to Barzel's essay." He also reports that he was influenced by Cheung's development-rights concept. Kitch emphasizes how the property-rights régime will affect the timing of diffusion:

"/Barzel/points out that the exploitation of technological information has much in common with fisheries, public roads and oil and water pools-all resources not subject to exclusive control. If the rule of first appropriation (emphasis supplied) controls, ther will be an inefficiently-rapid depletion of the resource. He
} 
its brilliantly engineered, quite unique Product $A$. It would be no mean thing for an alien railway company to be given vast tracts of land in a host country--surely at the present time! The only feasible alternative, deeply explored infra, may be to give the Company privileged positions in its otherwise unremarkable products B, C,. . The upshot belongs to a family of results I obtained from my analyses of full-line forcing and tied sales in 1960. (See Burstein(1960a, 1960b:)

free riding

An honest free rider "announces in advance his refusal to join a

suggests this problem can be solved if technological monopoly claims can be granted or auctioned off, giving their owner the exclusive right to develop the technological opportunity. What Barzel did not realize is that a patent system can be such a claim system and, indeed, that it is a more-sensible system than an auction system would be."

Kitch (1977), pp. 265-266

Kitch uses the idea of a prospect, i. e. "a particular opportunity to develop a known technological possibility." (Ibid, p. 266.) Kitch is concerned with premature depletion along lines based on problems such as overfishing. It may seem that his concern is opposite to ours: he is concerned about development that is too rapid; we are concerned about development that may be too slow. Such an impression is specious. In both his case and ours, entrepreneurs may require a pay-out period too short for social optimization. In both cases, efficient exploitation of social possibilities requires that property rights, be granted to the creators of new products. In both cases, a free ride, and hence a denial of such property rights, is socially counterproductive. 
coalition; the coalition makes its optimal choice knowing this. A dishonest free rider promises to join the coalition that proposes an undertaking for all its members. Then, having promised to join the group, so that the group acts on the basis of this promise, the dishonest free rider breaks his promise." (Lester G. Telser(1978), p. 2.)

Dishonest free riding is outside the purview of this study. But honest free riding is crucial for it.

The implications of free riding for the "decay" and related problems in the general case, encompassing developed economies of course, will be fully developed later in this paper. But some remarks on honest free riding and the patent strategies of less-developed economies usefully can be made now.

Denote economies with weak science bases and perhaps puny home markets as Beta economies. Why should a Beta economy offer patent protection if it can buy patented products from "pirate" vendors at lower prices?

Response is possible at two levels. One response-level can be developed without probing this paper's deeper reaches. It concerns such matters as quality control, delays in availability of new products in economies not offeris patent-type protection, blocked development of special products for Beta conditions and(in)sufficiency of appreciation of "clubbing" possibilities by Beta economies. I have explored this "response = level" elsewhere. (See Burstein(1983).)

The second "response level" is keyed to diffusion. Of course, for the most part this strand of analysis applies. to developed and undeveloped economies. The following remarks are specialized to the latter economies.

The central interest of host countries should be to achieve optimal diffusion of new knowledge. It becomes important for them not to become obsess $E$ : with "hardware". It is important that Beta economies not confuse the symbols of technological development with its reality. The "reality" is successfully wide 
and deep penetration of the knowledge permitting productive use of hardware almost surely contrived in more-advanced economies.

It will become clear that, typically, the interest of a Beta economy is to make it easier for innovating guest companies to keep command of the hardware around which growth-processes will cluster. Why? Because successfullycomplete diffusion is likely to require the sort of packaging(bundling) of hardware and goods and services complementary with it(including the physical products consumed by the process and the intangible knowledge necessary for optimal use of the machine) that only can be accomplished, surely in early stages of diffusion in less-developed economies by the innovating companies. Innovating companies best are seen as potential conduits for diffusion.

\section{THE CONTROLLING THEORY OF THE STUDY}

3.1. SOME FOUNDATIONS FOR A DYNAMIC THEORY OF MARKETING: MICROECONOMICS; THE PROBLEM AS VIEWED BY AN INNOVATING COMPANY

\subsection{0. preliminary coments}

Section 3.1.1. greatly simplifies the problem by assuming that the innovating company is diffusing(and therefore marketing)but a single product. In this way, we are able to isolate problems of timing. What is the optimal path of prices? Of promotional expenditure? Etc. Partly because of demandinertia and parthy because diffusion typically is enhanced by growing familiarity with products, so that today's sales significantly promote tomorrow's demand, at least for new and strange products, solutions typically call for frontloading of promotional expenditure and encompass the possibility that, if innovating companies could operate relative to long horizons, prices would tend to be discounted in earlier stages of product-diffusion.

The second subject of Section 3.1.1 intersects the theory of vertical integration. It is very hard to coordinate the marketing efforts of independent distributors of knowledge-based products, especially in early stages of diffusico. This can make vertical integration a preferred scheme of organization. But a 
feasible vertical-integration strategy requires retention by the innovating company of exclusive rights in the production and distribution of the product, possibly over a long reach of time.

Section 3.1.2 drops the simplifying single-product assumption. Robust final results require that we postulate n-product firms, the firms of the real world. The analysis of Section 3.1.2, heavily based on Burstein(1960b) and Telser(1979), "illuminates the principles of optimal pricing at a point in time; inter alia, it studies the pricing of complementary goods. (Indeed Sec. 3.1.1 establishes that today's output is significantly complementary with tomorrow's in the sense that demand tomorrow is influenced by knowledge acquired by working with today's output.) Section 3.1.2 studies bundled(vs unbundled)marketing in connection with provision of educational services by the innovating firm. And recovery of perhaps-immense front-end expense may require, along lines developed by Telser(1979), that a restricted set of bundles be offered; specific tie-ins may be called for.

Another theme of Section 3.1.2 is based on Burstein(1960). Feasible exploitation of profit-possibilities may require that clients be forced to buy their requirements (in fact whatever they choose to buy) of certain goods other than A(a much-esteemed product controlled by the Company)from the Company if they are to have the right to buy $\underline{A}$. A is the tying good. Tied goods include B, C; D. . . In this analysis, $(B, C, D, \ldots)$ may be unrelated to $A$ in demand and production. It may not be possible for the activity to be profitable unless a degree of con-

\footnotetext{
See also Burstein(1960a), Telser (1960), Warren-Boulton(1978) and R. G. D. Allen(1938), pp. 359-362. Re Warren-Boulton(1978), cf. esp. chs. 4 and 5 . The bibliographies of Telser(1979) and Warren-Boulton(1978) are useful.

It should be remembered that Allen(1938) is the first piece of work to be put on stream. Following authors, building on Allen, naturally were able to obtain fuller development of the material.
} 
trol can be established over the sale of (B, C, D,....). The costs of extracting the benefit from the use of A through some sort of multipart tariff for $\underline{A}(\underline{e}$. The surcharges on (B, C, D,...)play the rôle of a system of excise taxes. (See Burstein(1975).)

\subsection{1. the single-product case}

\subsection{1a. First Subject: Intertemporality}

Begin with a "verbal" exposition. Take a very simple two-period case: "today and tomorrow". Happily, the elementary case is illuminating.

Demand in the first period depends on prices (actual and expected)

in both periods. Costs can be ignored. The problem is to maximize the present value of the sum of first-and seconf-period revenues.

Discount rates affect choices of first- and second-period prices and so the pattern of diffusion. The higher the first-period price, the morefront-loaded will be the receipt pattern; the higher the governing discount rate, the greater the incentive for front-loading. At very-high discount rates, the Company would want to "take the money and run." It follows that policies imposing high discount rates (and therefore short pay-out periods) on technology-transferring companies can abort diffusion.

Turn now to a richer possibility. Recall the ogive-based sequence. The diffusion process proceeds slowly until a certain critical mass, measured by market penetaration(e. g. a "saturation" statistic) or the level of accumulated stock is attained. Then the process accelerates, later to level off.

Interpretation may run along these lines. Until the cumulant of diffusion reaches a certain critical level, it is not worth the while of any but very-heavily-capitalized entrpreneurs to invest in servicing or other ancillary industries. And that is where the free-rider problem reappears. It easily may become highly profitable for an outsider to break into the market 
without having to put up much capital because diffusion has reached its critical level. The market no longer needs to be educated so to speak. of course, innovators will not make massive investments needed to achieve critical levels of diffusion unless they can be assured of protection after that level has been attained.

To the extent that earlier sales comprise an input into the process generating later-period demand, current sales are profitable, not only to the extent that current revenues exceed current cost, but also because these sales increase future profits . Indeed, if innovating or technology-transferring companies can work to long-enough horizons, they make early-period sales lossleaders. 5 Early-period outputs then would exceed levels suggested by models insensitive to diffusion. Nor is the case peculiar. The value of telephone se:vice to a subscriber depends on how many others are hooked up.

algebraic analysis underlying the

"verbal" discussion just completed

We do not explicitly introduce discounting. This would clutter the argument once the qualitative effects of discounting are understood. With discounting, the optimal path of production shfits in accordance with a diminuexis effect: it pays to plan to cut down more trees now rather than later;it pays to sell younger wine; etc. The upshot, where $q_{1}$ is first-period demand, is

1)

$$
q_{1}=f\left(p_{1}, p_{2}\right)
$$

2)

$$
q_{2}=g\left(p_{2}\right)
$$

The problem is:

$$
\max p_{1} f+p_{2} g
$$

Necessary conditions for a solution are that the partial derivatives of the revenue function(we are able to neglect costs) with respect to $p_{1}$ and $p_{2}$

\footnotetext{
The locus classicus for this argument is Allen(1938), pp. 359-362. "For example a monopolist manufacturer of razors and blades may gain by marking down the pri $=\equiv$ of razors (for which the demand is elastic)below cost in order to promote the sa: $=$ of blades(for which the demand is less elastic and strongly complementary with ti: for razors." Ibid, p. 362 . Our counterpart to razors is early period sales".
} 
be zero. The resulting two equations are to be solved for $\left(\vec{p}_{1}, \vec{p}_{2}\right)$ :

$$
f+p_{1}\left(\partial f / \partial p_{1}\right)=0
$$

$$
p_{1}\left(\partial f / \partial p_{2}\right)+g+p_{2} g^{\prime}\left(p_{2}\right)=0
$$

Equation 4) simply states that, in the solution, the marginal profitability of a price change must be nil. But a lot of juice can be extracted from Eq. 5 . Consider a solution of $\mathrm{Eq}$. 5) at which $\partial \mathrm{f} / \partial \mathrm{p}=0$ : secon d-period price has no effect on first-period demand. Then note that, in the general case, .

$$
\partial f / \partial p_{2}>0
$$

It follows that, starting from a solution based on the assumption that second-period price has no effect on first-period demand, relaxation of that stipulation calls for a higher second-period price. The marginal profitability of an increase in the second-period price will be positive--starting from a solution conditional on the "partial" of first-period demand with respect to second-period price being nil; and then relaxing that condition. Ergo, the second-period price will be increased.

Now consider a crude scheme in which the strength of second-period demand depends positively on first-period sales:

$$
q_{1}=f\left(p_{1}, p_{2}\right)
$$

8)

$$
q_{2}=g\left(p_{2}, q_{1}\right)
$$

Conducting an analysis parallel to that of Eqs. 1-5), the problem is to maximize

9)

$$
p_{1} f\left(p_{1}, p_{2}\right)+p_{2}\left[g\left(p_{2}, f(\cdot)\right]\right.
$$

Setting partial derivatives equal to zero,

$$
f+p_{1}\left(\partial f / \partial p_{1}\right)+p_{2}(\partial g / \partial f)\left(\partial f / \partial p_{1}\right)=0
$$

I.

11)

$$
f+\left(\partial f / \partial p_{1}\right)\left[p_{1}+p_{2}(\partial g / \partial f)\right]=0
$$

And

$$
p_{1}\left(\partial f / \partial p_{2}\right)+g(\cdot)+p_{2}\left(\partial g / \partial p_{2}\right)+(\partial g / \partial f)\left(\partial f / \partial p_{2}\right)=0
$$

Implications already have been "verbalized". To repeat; when this perije's 
output generates demand in future(think of effects of a product becoming understood), its contribution to the present value of the Company's net proceeds arises not only from first-period revenues but also from the extent to which present sales promote future demand. A long view is built into rational calculations of innovating companies. However, such long-headedness can be offset or reversed by public policies imposing high discount rates (short pay-off periods) on innovators. 6

\subsection{1b Second Subject: Intersection of the Analysis with that of Vertical Integration}

Relying on Burstein(1960b), consider critical variables determining the properties of demand for a good(say a machine) marketed through a verticallyintegrated process. Surely they include the following:

a) retail prices at various outlets;

b) the number and location of such outlets;

c) the extent and kind of national advertising and other promotion

d) the extent and kind of local advertising, promotion and service-provision.

The "upstream" company, controlling the patents, etc., would study the conditions of manufarturing and the demand-possibilities. Then it would settle on an optimum mix of control variables: the profit-maximizing combination of retail prices, number and location of outlets, national and local advertising, special-service provision, etc.

As the problem has been put, it is hard to see how, in the real world,

6 In more-realistic formulations, the demand function at date $\underline{t}$ might be written

$$
q_{t}=f\left(p_{t}, p_{t+1} \cdots p_{t+T^{\prime}} \int_{0}^{t} \psi(t) d t\right)
$$

I. e.. the cumulant of past sales affects demand at any date $\frac{t}{\text {. }}$. Subsequent derived innovation similarly could be a function of such a cumulant. 
it could be solved except within the organization. ${ }^{7}$

I have explained the problem at hand, albeit in a slightly-different context, as follows (giving due credit to Telser(1960)).

"A familiar dilemna confronts manufacturers...High prices to distributors might lead to their finding it unprofitable to push the item; low prices to distributors might lead to a good deal of promotion...but perhaps profits simply would. go to the distributors.

"Sans vertical integration, the solution runs.as follows. Use the carrot and the stick. Set the wholesale price low enough to permit substantial mark-ups and encourage local promotion. Require wholesalers to purchase all their 'requirements' of other goods--over which you have less market power and which otherwise may be unimportant to you--at a price substantially above your cost."

$$
\text { Burstein(1960b), p. } 85
$$

Cobviously, the multiproduct analysis of Section 3.1 .2 exerts a

strong pull on the restricted analysis of Section 3.1.1. Just as obviously, implications for diffusion of patented lead products, especially in markets of less-developed economies, are near to hand. It proves impossible to treat one, among many, products in a company's line in isolation.)

In 1960, as in 1983, potential internecine strife among distributors posed an especially troublesome difficulty. Uninhibited competition among distributors is inefficient. Thus Distributor $X$ does not put a positive value on stimuli of demand for other distributors' products caused by his ReqD, promotional and advertising outlay. Optimality of an unintegrated markęting scheme requires the equivalent of formation of complex coalitions of distributors whose

Toliver Williamson would say that the problem appears to call for a heirarchical, rather than a market, solution. Going back to a locus classicus, vis Coase (1937; , the technical problems of establishing a price system and communications network encompassing the "upstream" producer and putative independent "downstream".entities capable of solving the problem might be insuperable or, if feasible, the solution could be obtained only at an unacceptable cost. 
members could, in effect, agree to slice up a maximized joint melon. And resulting "supernormal" profits would have to be "taxed away" by the upstream "monopolist"(e. g. patentee) for the upshot to be worth his while. In reality, distributors would have to be tied up in knots. In reality; optimal development of property rights in knowledge-based products probably typicaliy requires that distributors'simply be taken over (or never let go)by innovating firms--surely in early stages of product-diffusion. The analogy to bundled marketing lies very close to the surface.

\subsubsection{The Multiproduct Case}

\subsection{2a. Preview of the Subsection}

Overheads--here importantly in the form of costs sunk in productintroduction, user education, etc.--may not be recoverable unless a large-enough product-1ine can be established and protected, especially if property rights in "spin off" are not created. The field over which the innovating firm exercies control may have to be enlarged so that a quite-broad product-group is encompassed. This problem occupies Section $3.1 .2^{\mathrm{b}}$ and was studied by Burstein (1960a, 1960b) in a related context. A more-difficult line of analysis, based on Teiser(1979), occupies Section 3.1.2c. It is based on the frequently-strong complementarity between knowledge-based lines (a commanding example again concerns hardware/software). The analysis establishes that a marketer may not find it worthwhile to offer rich packages of complementary services unless he freely can form groups (bundles) of complements geared to different sorts of users. Stringent protection of intellectual property may be necessary to induce sufficient marketing effort.

\subsection{2b. Creation of Product.Fields in Order to Appropriate Sufficient Revenues to Justify Introduction of a New Product(perhaps in a foreign economy)}

The controlling problem can be put in the following way. A host economy wishes to maximize consumer benefit from a set of products innovated 
by Company C. The Company's active participation in the diffusion of these knowledge-based products proves indispensable for the solution of the problem.

Often in problems of economic policy the most attractive policyavenue is blocked. We assume that it is politically and/or technically infeasible for the host economy to offer a lump-sum subsidy to the Company to induce it to offer a socially-optimal set of products, promoted (socially) optimally, priced (socially) optimally, etc. Indeed, in the real world, it probably is inherently infeasible to . try to operate along such lines. One cannot know what will be the fruits of new knowledge. The problems surrounding propagation of knowledge-based products and their associated technologies usually cannot be quantified ex ante.

Further reinforcing the inherently open-ended nature of a feasible solution, a potential host country cannot, at any point in time, know the products it should especially covet.

The appropriate problem concerns construction of an optimal feasible standard operating procedure. Any procedure must respond to the fact that, for the game to be worth an innovator's candle, it must be able to anticipate achieving a rate of return at least as great as some minimum level. the-minimu-acceptablo-expocted-rate- of rotum-nt.

All the programs consistent with the constraint may require that protection be afforded to many products. Thus the feasible program conferring the largest benefit to the host economy might require protection of the Company's markets for many products.

exposition of the "extended protection" theme

The argument can be deepened by exploring a modification of an example from Burstein(1960b). Assume that all consumers of a product the Company can develop for $\$ 10$ million can be represented by the same demand curve. See Diagram One, If the Company were constrained simply to establish a one-part 
tariff(a single price), it would charge $\$ O A$ per unit and sell (n)(OB) units. There are $\underline{n}$ customers. Marginal revenue is nil at price $O B$; the analysis can be kept clean by ignoring cost. Total benefit/(n)= Area $\alpha$. Total revenue $/ \mathbf{n}=$ Area $\beta$.

It is quite possible that total revenue (here equal to profit before capital costs) cannot justify the $\$ 10$ million investment. Yet. social benefit may be massive. And it is easy to identify the rub: the restriction imposed on the Company's pricing policy makes it impossible for it to appropriate enough of the benefit to justify a $\$ 10$ million investment.

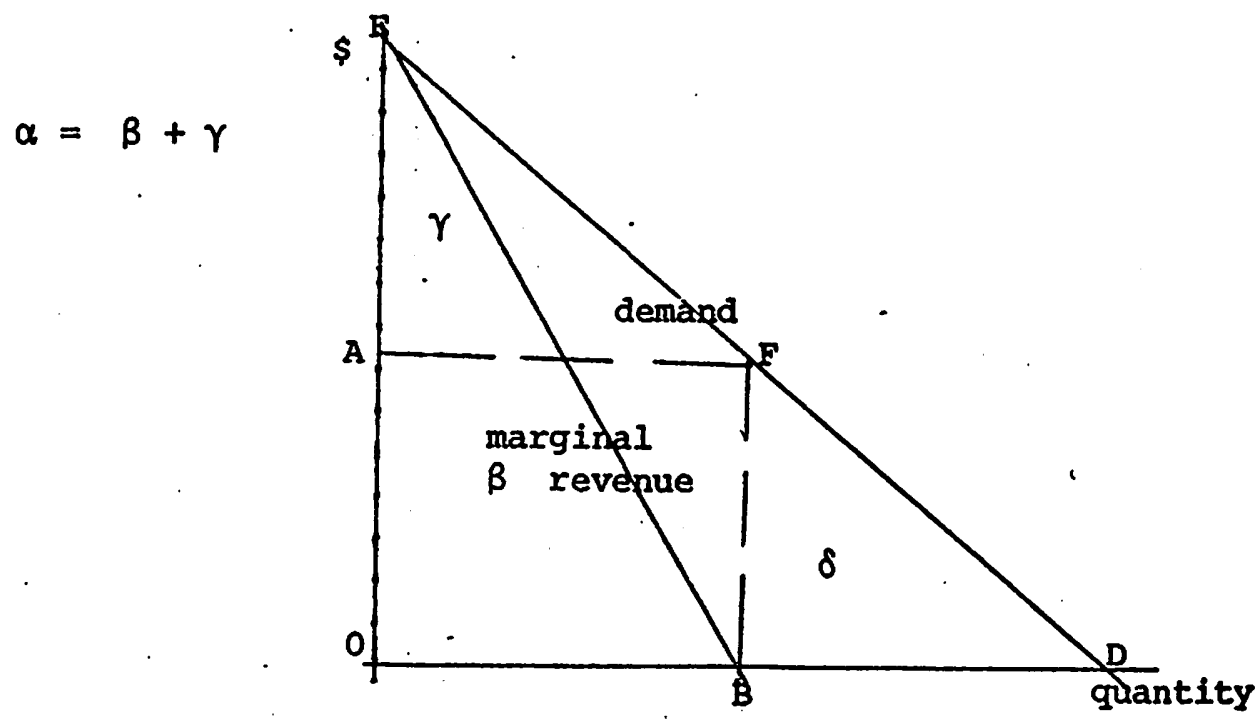

DIAGRAM 1: The Representative Demand Curve: Illustrated

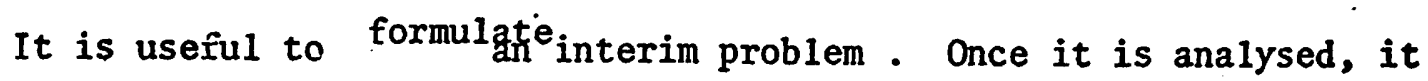
can be transformed into. the "confrontation" that truly interests us, that between the Company and the Government of the host economy.

The Interim Problem. Let ED represent the demand for coffee (of the representative consumer)faced by a coffee monopolist. If constrained to obtain his revenues from a single-part tariff, the monopolist (miraculously able to suppl: coffee costlessly)would charge $\$ O A$ per cup and obtain revenue of $\$ B=\$ O B F A$. But he will see that maximum revenue in an unconstrained solution is $\$ \mathrm{ODE}=\$\left(\alpha+\frac{\pi}{;}\right.$. 
\$ODE can be extracted from the market in an interesting way. Each customer can be told:

to have the right to drink all the coffee you want at zero price (equals marginal cost), you must pay me an annual fee of a bit less than $\$(O D E)$.

This tactic maximizes benefit and then expropriates all of it. It leads both to profit maximization and social efficiency in the sense that benefit is maximized.

Assume that the Company is released from the single-tariff restriction but is not allowed to impose a user charge. A strategy that would preserve some, but not all, of the advantages of a $\$$ (ODE) user-charge would be the following:

the company imposes a set of excise taxes. In effect, it has been bounded away from imposing lumpsum taxes. (See Burstein(1960a, 1975).) The taxes are defined by the differences between the prices the Company charges for certain tied goods and the competitive prices the consumer would pay if he opted out of the"coffee game".

the consumer is told:"if you are to have the right to buy coffee from me at price $p$ (here zero), you must buy your requirements of products $\left(x_{2}, x_{3}, \ldots, x_{n}\right)$ from me at prices $\left(p_{2}, p_{3}, \ldots, p_{n}\right)$." The array of excise taxes

This sort of arrangement is called a full-1ine force. If it can be imposed, the $\$ 10$ million investment may become attractive to the Company.

The Proper Problem: The Company and the Goverment. Abstracting from \&i) expeccrly uncertainty for now, the Government of the host economy is assumed to see that: $<$, i) the Company cannot recover its investment if its property-rights position is confined to the power to establish a single-part tariff for $x_{1}$, the product prized by the Government; $i$ i) if the Company's patents for products $\left(X_{2}, \ldots, X_{n}\right)$ were recognized by the Government, and it were free to use a profit-maximizing price-strategy, it would find it attractive to operate in the Beta economy under study.

The proper problem differs from the interim problem in at least two 
significant respects:

I) in the proper problem, the idea of recovering some sort of overhead--essentially by allocating it, or distributing it, among a number of profitable products instead of just one--is important. This idea has no place in the interim problem.

2) the two-person (non-zero-sum) game between the Company and the Government differs substantively from that of the interim problem in ways immediately to be explained.

An agreement between the Company and the Government would find the latter abjuring opportunities to buy products $\left(\mathrm{X}_{2}, \ldots, \ldots, \mathrm{X}_{n}\right)$ at prices (II)-$\Pi<\Pi+\tau$ !--from "pirate" sellers. In return the Company would make a $\$ 10$ million investment in a diffusion process that may spin off substantial further gains to the Beta economy. ${ }^{8}$ And $x_{1}$ not only would become available; it also would be explained. And complementary products too would be explained. Up to this point, the analogy to the games of my earlier work, and of the interim problem, is quite tidy. The difference between the two problems is the following. In the "proper" problem, Beta consumers do not face tie-ins or full-1ine forces. Instead the Government decides to submit to a virtual "force", albeit only in the sense of recognizing, instead of disregarding, valid patents.

Perhaps the most.interesting similarity between the interim and proper problems lies in the way in which in both cases the Company extracts revenue from an enlarged product-field.

\section{uncertainty}

In real-life situations the Government may not be able to determine which is the lead product. A pleasing feature of the solution to the proper problem is that the Government need not try to find out. The solution just obtained simply calls for a standard operating procedure under which protection is

\footnotetext{
"In the real world, it is unlikely that "pirate" prices obey a pure-competition norm. Instead, they are likely to float not much below prices set by patentees.
} 
accorded to a number of patented products; a number of patents are respected. This done, the Company's self interest will assure that what proves to be the lead product indeed comes to the fore.

Intermezzo: notes on decay of the appropriability-potential (cf Pakes: \& Schankerman(1978))

It has become established in modern economics that many politicaleconomic policies, even if optimal, lead to regret,pace a critical necessary condition of dynamic programming. (Cf Sheffrin(1982) for a good summary of the state of play.) An oft-cited illustration is patent policy. Once patents are granted, and once patentees have sunk costs, the state will regret that its longer-run interests dictate that the rug should not be pulled out from under the patentee. Thus, if no further invention from any source is anticipated(l), why not revoke protection and get the fruits of the patented inventions more cheaply? of course, in the dynamic real world, such regret easily is outweighei by continuing benefit from stimulation of further invention.

The important, if eccentric, point just made applies to our analysis. Once an innovating company has sunk substantial diffusion and other more-or-less introductory costs, it normailly will plough ahead even if the Pakes-Schankerman $\delta$ factor i: loples : marked attrition of appropriable revenues: the marginal costs of continued exploitation of the Beta market are apt to be quite low once diffusion is far advanced. The critical decision concerns sinking substantial diffusion cost in the first place. 9

**

The Pakes-Schankerman problem can be schematically developed in an illuminating way.

9. A chemical company may contemplate building a very expensive plant dedicatec a new process. Capital costs will be high. Operations-costs (at least net of petroleum feed-stock) will be low compared to a conventional plant. Once built, the plant will continue to be operated even if the decision to build comes to $k=$ rued. 
The dynamic relationships between a shift parameter standing proxy for the degree of diffusion ${ }^{20}, \alpha$, and the expropriability (of profit) factor, $\delta$, are supplied by differential equations 13) and 14).

$$
\begin{aligned}
& \dot{\alpha}=\phi(\alpha, \delta) \\
& \dot{\delta}=\psi(\alpha, \delta)
\end{aligned}
$$

And :

$$
\begin{aligned}
& \partial \psi / \partial \alpha<0 \\
& \partial \psi / \partial \delta<0
\end{aligned}
$$

Expropriability-potential falls as the market becomes more"saturated"

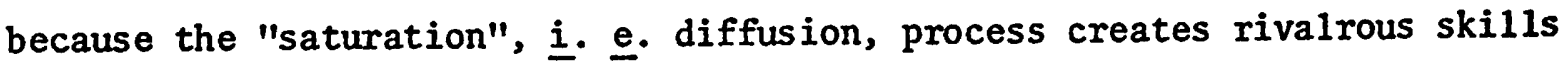
in ways already described. (Cf. Inequality 15).) And the higher the level of the appropriability-factor, the jucier is the target. (Cf. Inequality 16).) Equation 13) is apt to be importantly non-linear. Its analysis belongs to that of the "pure" diffusion process. Cf supra.

It suffices here to note that an innovator, aware of the properties of Eqs. 13) and 14), will choose conditionally optimal paths such as say $\Phi\{t\}$, describing promotional expenditures as a functional on time. The "conditionally optimal path" will depend on alternative régimes of property-rights in obvious ways. And choice of the régime should be sensitive to the properties of the economic structures just delineated.

Law and economics deeply penetrate eachother in this, and many other, instances.

3.1.2c. Marketing and Diffusion of Complementary Goods

${ }^{10}$ cf $\quad q^{d}=f(p, \alpha)$.




\section{Telser's Theory}

As we have seen, R. G. D. Allen(1938) showed that a monopolist of both razors and razor blades well might sell razors below cost in order to stimulate demand for razor blades. And it has become clear that such a strategy depends on the seller being able to appropriate blade revenues.

We also have seen that there is intrinsic complementarity between knowledge-based goods and the techniques embodied in associated services (often called "software" here). Also that, especially in early stages of diffusion, current sales may be complementary with future sales in the sense that increased familiarity with innovative products breeds increased interest in and comprehension of them, in turn causing demand curves in future to push out rightwards. Telser expands this bridgehead. (See Te1ser(1979).)

Telser posits that there are $\mathrm{m}$ components that can be combined to make up $\underline{n}$ goods. Thus a certain drug, together with the services of a doctor who has received training from the innovating pharmaceutical house, comprise three components combined to make up one good, $\underline{i}$. $\underline{\text {. }}$ treatment of patients in the specified way. The "molecule", the training and the doctor's work are the three components.

Telser first shows that, if the "monopolist" were confined to selling components--if he were prevented from selling bundles of components comprising goods--he would, in general, sell some of the components below cost.

He next shows that, if bundling is feasible, and if the $\underline{m}$ components are complementary, 12 it would pay the Company to sell a particular bundle (good) rather than the component parts. He thus constructs a proper theory of bundled marketing.

11. "For m complementary commodities(components), a good is an appropriate combination of these $m$ constituents. The good is incomplete without all of these constituents. For $m$ substitute commodities, each of them contains the same goo: to some degree. Therefore, there is a set of prices, one for each of the $m$ sutstitute commodities, such that one dollar's worth of each of these $\underline{m}$ commodities is essentially the same good." Telser(1979), p. 226. 
Telser(1979) is completed by a section called "The Free Rider

Problem":

\begin{abstract}
"Assume that commodity 1 cannot be sold separately at a positive price. Perhaps /it/ is information about another commodity 2 that a potential buyer of commodity 2 can obtain from those who sell it... Commodity 2 may be a new product sold by retailers some of whom furnish information about it to their potential customers. There is a free-rider problem if customers can obtain information about the product from one retailer who charges nothing for this service and then buy the product at lower ${ }^{a}$ price from another retailex who furnishes little or no information about the product... /The second/retailer can obtain a free ride at the expense. of the first retailer. This situation cannot persist."

Ibid, p. 228

"The manufacturer wishes to have a method of distributing the product, commodity 2 , so that no retailer can obtain a free ride at the expense of another. The optimal policy should tie the information and the physical commodity together so that the physical product cannot be sold by a retailer who does not provide the information. A method of solving this problem is to set a minimum price on commodity $2 \ldots$. Then/ all retailers have an incentive to furnish the information necessary to sell the product to retail customers."
\end{abstract}

Ibid, pp. 228-229

Our version of the free-rider problem--discussed by Telser(1960) and Burstein(1960b); and reassessed by Telser(1979)--plays out over time. Here sales at Date $t$ contain, or generate, information about the perhaps- . physically-identical product sold at Date $\underline{t+h}$. We study a dynamic free-rider problem whose logical structure closely corresponds to the familiar static one. Further Transformation of Telser's Theory

In Telser's problem, consumers have all the information, together with the ability optimally to deploy information, pertinent to putting together the components of goods(final products). Bundling is but a function of monopoly power. No consumer has need for a bundle instead of a set of components. One thinks of a brilliant public indifferent between acquiring a fabricated mockGeorgian table or a kit of broken-down. components; or indifferent between buyin stereo sets or their components; or, evoking earlier days, indifferent between buying completed model-airplanes and kits containing balsa-wood parts, rubber 
bands, etc., together with incomprehensible manuals. Our problem concerns a much-less-adroit public!"Our" public would, at least in early days of diffusion, be unable to make anything of the manuals; the kits would be quite worthless to it. Markets would exist only for bundles, i. e. for completed model planes. True, the markets would evolve towards "Telser's market" as information and comprehension deepened and expanded in the course of the diffusion process. Intensifying the line of attack just launched, at the outset of many diffusion processes, only innovating companies may be able to assemble the bundles. True, this likelihood will tend to be smaller in more-advanced economies. There generalized conceptual and technical skills will be thicker on the ground, perhaps enabling consumers or independent software houses fairly quickly to work out assembly processes; and indeed sometimes to develop advances uses that may not have been foreseen by the Company.

Moving forward from very early stages of diffusion, innovating companies often would want to compel bundling for reasons rather different from those animating Telser's monopolists. The Companies will become concerned about promotion of enhancements of the simple programs imbedded in the bundles initially supplied to the market. ${ }^{22}$ Along the lines of the razor/razor blade parable of Allen(1938), companies may find it in their interest to

$$
\text { .. give away educational services (and even pay potential }
$$

buyers of enhanced prograns to take courses at spas)in order to prevent stagnation of the market(to take a defensive line); and to facilitate market breakout(suggesting an offensive strategy along military lines).

The logic of a compulsory bundling strategy resembles that of compulsor: public education. It is expected that the students, whether Beta entrepreneurs $\equiv$ d

\footnotetext{
${ }^{12}$ Computers once were for the most part batch-processing units and, indeed, glorified accounting machines. It took years before a mass market developed for computers as agents for conceptual thinking, a market that now is rapdily accelerating.
} 
households or children, will absorb knowledge and acquire skills that they cannot be expected to comprehend before, and even while, they are being schooled. In retrospect, most will be glad they were forced to go to school. Needless to say, being forced to buy a package including the right to be educated is not on all fours with marching to school under the baleful eye of a truant officer. And, after all, the Company could offer instruction to a11 comers.

"Instruction to all comers" would be an unfiltered process. Purchasers of the packages(bundles) are identified as high-potential prospects for a costly training. Money spent on walk-on students almost surely mostly would be thrown away, surely if hardwere is available from others!

True, bundling in of educational services is quasi-compulsory, not compulsory. But it suffices that, in the upshot, the probability that susceptible users will become trained in the theory and praxis of the knowledge-based product increases, perhaps very substantially.

\section{spin-off}

Spin-off occurs in at least two directions. One direction concerns the equivalent of energy waves radiated towards other Beta activities. Another concerns the Company. Demand for enhancements of the "programs cum: hardware" originally sold, together with that for new products, some not even initially envisaged by the Company, will increase. The upshot confirms a conjecture of

\section{Telser:}

"...the seller could then choose $p^{\circ}$ lhere the price of the hardware] to maximize profits; and this would give him the maximum amount the customers would [here, after being educated] be willing to pay. Observe that in effect every comodity [here including education] is given away 'free' except for the first commodity." (Telser(1979), p. 227.)

\section{bundling fades away}

Ultimately, it will be in the interest of the Company to abandon bundiris: diffusion of knowledge about the products and their uses will have become so 
complete that the market will be able to fabricate bundles more complex and varied than the Company can hope to put together. Finally, the Company may have no choice: competition, intensified by the expiration of patents, may. become too hot for the Company to be left with choice of packaging. A profitably successful diffusion process will give way to a régime of competition.

\section{**}

coda to Section Three

A successful diffusion process is synergetic: it generates external economic benefit as well as its own "consumer surplus"; feedback from these "external technical economies" will enhance the productivity of the products and processes being diffused. Unlessprofit tapture possibilities are extended to encompass processes external to prime innovative products, knowledge-based economic progress can be blocked.

Still, due to the complementarity controlling much of the analysis, spin-off also enhances demand for related Company products. Such enhancement inevitably results from intensification of activity on feedback channels. Marketing effort in the direct channel leads to spin-off that activates demand on a feedback channel that will be profitable for the innovating company to some extent. The economic system controlling the decisions of innovating companies is closed to some degree.

\section{A DYNAMIC MACRO-ECONOMIC ANALYSIS OF EFFECTS OF DIFFUSION OF KNOWLEDGE-BASED PRODUCTS}

Section 4 studies problems associated with diffusion of knowledge-based products from a fairly-strictly macro-economic viewpoint. It is organized around effects on the level and growth of per capita incomes of Beta economies, together with effecs on balances of payments, domestic savings, etc.

Section 4.1 is concerned with quite-specific macro-effects. Section 4.2 reminds us that technology-transfer can be expected to lead to disembodied technical progress, equivalent to a persisting gentle rain of progress that one 
cannot strictly identify.

\subsection{Specific Macro Effecs of Effusion of Knowledge- Based Products}

We have seen how a feedback channel(i. e. a channel propagating economic energy from the market back to the Company)would lead to changes. in Company activity. And there would be propagation in other directions, directions not amenable to appropriation of revenues by the Company. We capsulate this analysis by constructing a standard diffusion scenario.

the standard diffusion scenario

Once the feedback channel is activated, and other induced creative activity gets under way, initial purchasers of patented products and processes may themselves become innovators. They may become the first to plunge into the newly-created set of possibilities. "Energy waves" emitted by primary innovators will stimulate users of their products to come up with ideas of their own. These ideas, comprising new uses of products or new wrinkles in operating processes, will be relayed back to primary innovators who will benefit from this feedback. And demand for skilled labor will be generated, permitting Beta workers profitably to upgrade their skills. Important productivity gains might follow.

Second, third and later waves of technology-transfer may unfold as an increasingly-more-sophisticated Beta economy hits upon uses for innovating companies' products and processes that the Companies themselves may not have foreseen.

The first wave of technology-transfer will be provoked by impulses supplied by innovating companies. Following technology-transfers may be in response from host countries. Such "after shocks" stimulate working of patents. ${ }^{12}$

\footnotetext{
${ }^{13}$ I discuss working-of-patents in Burstein(1983). A central conclusion is that in many circumstances the best evidence of "working" is the degree to which the upshot stimulates imports, not that to which local manufacturing activity is engendered.
} 
The"standard diffusion scenario" recently has been enriched by Gustav Ranis(1983) in the course of his explanation of the contrasting growth experiences of Latin American and East. Asian economies:

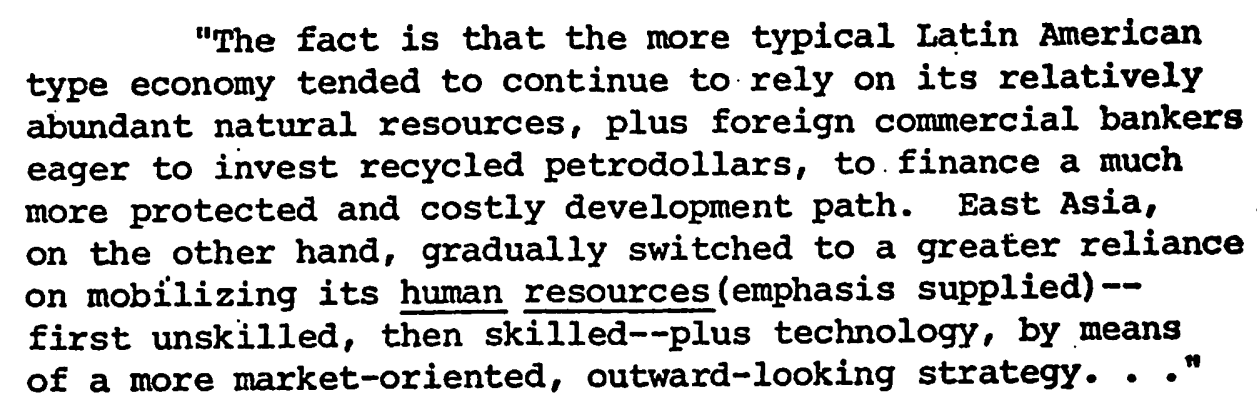

extension of the standard scenario: the balance-of-payments dimension

We have seen that impulses transmitted along the feedback channel induce demand for additional Alpha techniques. And a burgeoning middle class, an inevitable concomitant of accelerated economic development, will demand sophisticated consumer products. Development may get shot down by balance-ofpayments crises that can be averted if demands for sophisticated consumer products can be satisfied at home. It follows that, unles's a secondary technologytransfer, rapid enough to foster enough import-substitution to avert a balanceof payments crisis, is induced, the Beta development process can become aborted.

A uniquely-macro-economic element has entered the analysis. The

secondary technology transfers necessary to foster import-substitution will : I 10 outside the domain of activity of the innovating companies who kicked off the macro-growth process. Not even an immense multi-national company occupies enough economic space to make it worthwhile for it to promote secondary technology-transfer sufficient to permit substitution for sophisticated consumer, and other, demands otherwise met by imports.

Protection of intellectual property now is brought into the middle of the field of play.

Accelerated Beta growth will induce many applications for licenses to use Alpha products. And it may trigger direct entry of Alpha producers: it 
may come to look profitable to them to set up factories and marketing organizations in a booming economy.

Entry by Alpha producers, even if urged and abetted by the Beta government, would be discouraged by worry about ability to repatriate revenues earned in Beta either because of depreciation of the Beta dollar or a collapse of the foreign-exchange process converting earnings of Beta-based subsidiaries into host-country currencies. Aternatively, the upshot could.be short required pay-out periods; Alpha companies would apply high discount-factors to expected earnings from operations in Beta: the companies would plan on receipts profiles characterized by diminuendo instead of crescendo. But we have seen that optimal diffusion of knowledge-based processes typically works to long horizons.

The controlling logic that must be obeyed by Beta authorities is this. The accelerator principle of investment requires that large, more-orless short-term, capital expenditure be made in order to generate a flow of "sophisticated" consumer goods. The "machinery" in question doubtless will hare to be imported from Alpha sources. There will be a "blip" in the imports(defined on time) curve. Resulting deterioration of the current account must be financed by capital inflow. Consequent increased debt he to by foreigners must be serviced over the life of the "machinery" by subequent improvement in the Beta current account. As Ranis (1983) points out, one source of current-account improvement is continued expansion of knowledge-based industry in Beta: once over the hump(blip), such expansion will put much less strain on the Beta balance of payments because of the operation of the accelerator principle. And, as Ranis also points out, failure of a capital-inflow episode to trigger a. development-process that stimulates the Beta current account in future can be, and has been, quite disastrous.

"Beta-ization" requirements: further strain on the balance of payments 
Balance-of-payments logic frequently is violated along the following lines.

Beta governments often require that innovating companies penetrating Beta markets take in Beta partners and agree to surrender the technology they bring in to Beta entrepreneurs, or the Beta government, quite soon.

We already have seen that, even if such requirements do not simply prevent transfer from occurring, resulting high internal discount rates will prevent optimal diffusion.

Even if mandated transfers of control to Beta entities were to be accomplished at fair-market values, ${ }^{14}$ such Beta startegy would be counterproductive. Strains on the balance of payments would be exacerbated at the same time that capital inflows were discouraged. And domestic capital would be squandered. It simply would replace foreign capital hounded out of the country instead of financing local investments clustering around influxes of foreign capital, some exogenous, some induced by enlarged Beta opportunities in the wake of initial innovative investments in Beta.

\section{Coda to Section 4.1 .}

Two rather-intricate problems have been left as isolated islands of resistance so that Section 4.1 could flow smoothly. The first concerns the quitecommon real-life strategy of imposing minimum investment programs on Alpha entrepreneurs as a condition of Beta cooperation. The second problem concerns a wrinkle imposed by modern macro-consumption theory. This "wrinkle" suggests that the very prospects of accelerated development of the Beta economy could lead, promt.

14 Such fair-market values would be determined relative to effects of a sub-optitr? Beta policy. Resulting values might be far less than going-concern values basec on uninhibited opportunity to deploy Alpha intellectual property and complementer? devices. 
1y to a lower savings-ratio so that all the more capital would have to be attracted from abroad. And, to the extent that prospects of higher permanent income encourage acquisition of larger stocks of sources of consumer services (i. e. consumer-durables), there will be a blip in consumer expenditure(to be distinguished from consumption) that typically would put severe pressure on the current account of the Beta balance of payments.

\section{minimum-investment requirements}

If an Alpha company is required to invest more capital than it deems optimal, it must contemplate what Keynes called a lower marginal efficiency of capital than otherwise it would expect to achieve. It follows that it is quite possible that less, not more, capital will flow into Beta. And it is certain that what capital does flow into Beta will be used sub-optimally. Indeed such a policy would do the most harm to the extent it seems to have worked! Any resulting over-investment, relative to projects put into place, will cause permanent strain on Beta resources: either more resources, net of revenues earned by the projects in question, must be dedicated to service of foreign debt or the balance of payments must collapse, doubtless with spasmodically-constrictịve effects on foreign trade.

\section{negative effects on savings ratios}

It is well known in macro-economics that the expectation of higher income in future, or an increase in net financial wealth leads to reduced saving. from current measured income. ${ }^{13}$ This proposition, when combined with one in investment theory, puts a double whammy on a Beta balance-of-payments in certain important circumstances. If Beta households become convined that discounted values of net future receipts are going to increase, they logically will step up consumption(reduce saving)now in order to even out consumption 
streams over lifetime. And firms, anticipating increasingly-buoyant demand, will expand their plant and equipment in order to be better placed to satisfy demand when it comes on stream. Both forces work towards a shortfall of Beta saving relative to Beta credit-demand. Balance-of-payments.equilibrium then requires increased capital inflow.

\subsection{Disembodied Technical Progress}

"We start with disembodied technical progress which applies equally and alike to all resources of men and machines in current use... Such technical progress represents technical know-how falling like manna. from heaven... We turn next to technical change in some variety or other of embodied technical progress. This applies, not to the whole range of available resources, but only to certain tranches of capital equipment... Capital is no longer assumed to be homogeneous. On the contrary, capital becomes essentially a mixed stock of different 'vintages'. Machines of one vintage are different in kind from those of another; because of embodied technical progressm new machines are more productive than older/ones/."

$$
\text { R. G. D. Allen(1967), pp. 236-237 }
$$

Disembodied technical progress pertains in an obvious way to the problem of unexplained growth in output. "Only 40 per cent of the growth in output/in the United States/ is explained by input growth." (Branson(1979), p. 529.) The large residual must be explained by technical improvement of human and non-human capital. Our micro-economic analysis concentrated on embodied technical progress. But it is natural for a macro-economic analysis to assign a large rôle to disembodied progress.

Disembodied progress is pure spin-off of a sort not directly capturable by innovating companies. The narrow calculations of innovating Alpha companies do not account for the extent to which Company actions contribute to what will be identified as disembodied technical progress. So it is all the more important that the authorities controlling Beta economies do so. If they do so, they logically will widen the range of concessions offered to innovating Alpha companies. (For the most part, such concessions are in the form of grants of 
property rights in products and ideas of proved originality.

\section{Concluding Pemarks \\ In $m y$ end is my beginning. \\ T. S. Eliot, East Coker}

The modern theory of economic develop takes an intensive, not an extensive, view of the growth process. For it, economic development mostly consists of doing different things in different ways; importantly because of effects of growing knowledge.

Starting from many points, we repeatedly concluded that the proper concern of public policy in the field of knowledge-based products and processes is not the net revenues that innovating companies might recover from their sometimes immense research-and-development expenditures; but rather the revenues that are not appropriable by them. The dog that does not bark is more important than the one that does. A crucial risk run by developing, or developed, economies is that of stifling progress based on the diffusion of knowledge by making too-paltry grants of property rights in knowledge-based products and processes; not in the quasi-rents of innovators.

The most interesting twist of the analysis is made necessary by the often clogged channels of direct appropriation of social gain from innovation. In football metaphor, the innovator-passer, looking downfield, often finds his primary receivers covered and must pass off to secondary ones: feasible diffusion of knowledge-based products often requires that the product-space allocated to the innovator by grants of property rights be larger(contain more dimensions), perhaps much larger, than one confined to primary invention.

\section{Works cited}

Allen, R. G. D. (1938), Mathematical Analysis for Economists(London: Macmillan \& Co., Ltd.)

Allen, R. G. D.(J967), Macro-Economic Theory: A Mathematical Approach(New York: St. Martin's Press) 
Barzel, Yoram(1968), "Optimal Timing of Inventions", 50 Review of Economics - and Statistics 348

Burstein, M. L.(1960a), "The Economics of Tie-In Sales", 42 Review of Economics and Statistics 68 (No. 1.)

(1960b), "A Theory of Full-Line Forcing", 55 Northwestern University Law Review 62 (No. 1.)

(1975), "Review of W. S. Bowman, Patent \& Antitrust Law, etc.". Journal of Economic Literature

(1981), Testimony before the Small Business Committee, Subcommittee on the General Oversight, U. S. House of Representatives, Hearing, Sept. 21, 1981, published by the U. S. Government Printing office in 1982.

(1983), "An Economic Analysis of Effects of Protection of Intellectual Property on Economic Development: Public Interest and Private Profit", unpublished

Coase, Ronald(1937), "The Nature of the Firm", 4 Economica 386 (Nov.)

Friedman, Milton(1957), A Theory of the Consumption Function(Princeton: Princeton University Press).

*Branson, William H. (1979), Macroeconomic Theory and Policy, 2nd ed. (New York: Harper \& Row)

Griliches, Zvi(195-), "Hybrid Corn, etc.(sic)", Journal of Political Economy

Kitch, Edmund พ. (1977), "The Nature and Function of the Patent System", 20 Journal of Law and Economics 265 (Oct.)

(1980), "Reply to Smith \& McFetridge", 23 Journal of Law and Economics 205 (Apr.)

Modigliani, F. \& Brumberg, R. E.(1954), "Utility Aanalysis and the Consumption Function" in K. K. Kurihara(ed), Post-Keynesian. Economics (New Brunswick, N. J.: Rutgers University Press)

Pakes, A. \& Schankexman, M. (1978), "The Rate of Obsolescence of Knowledge, Research Gestation Lags and the Private Rate of Return to Research Resources", Discussion Paper No. 659 (Cambridge, Ma.: Harvard Institute of Economic Research).

Ranis, Gustav(1983), "For Latin American Economies, Lessons in Asia", Wall Street Journal, October 12, 1983 (p. 34).

$\forall$

Smith, Douglas A. \& McFetridge, Donald G. (1980), "Patents, Prospects and Economic Surplus, 23 Journal of Law and Economics 197 (April) 
Telser, I. G. (1960), "Why Should Manufacturers Want Fair Trade", 3 Journal : of Law and Economics 86 (Oct.) Press)

(1979), "A Theory of Monopoly of Complementary Goods", 52 Journal of Business 211 (No. 2, Apr.)

Trajtenberg, M. (1982), "The Effects of Regulation on the Diffusion of CT Scanners (Cambridge, Ma.: National Bureau of Economic Research)

Trajtenberg,M.:=\& Yitzhaki, S. (1982), "The Diffusion of Innovations: A Methodological Reappraisal", (Harvard University/National Bureau for Economic Research, unpublished)

Warren-Boulton, Frederick (1978), Vertical Control of Markets (Cambridge, Ma:: Ballinger Publishing Co.)

$\Varangle$ Sheffrin, Steven(1982)，Rational Expectations (New York: Cambridge University Press). 